\title{
Índice por autor -2008
}

ALMEIDA, Gabrielle Oliveira

Feirante ou barraqueiro? Identidades e estratégias na Feira do Jubileu

v. 8 n. 17 p. $70-87$ mai./ago. 2008

ÁVILA, Marcos Gonçalves

O fenômeno da maldição do vencedor em leilões: um estudo experimental no ambiente brasileiro v. 8 n. 16 p. $11-29$ jan./abr. 2008

BEZERRA, Francisco Antônio

Descrição da estrutura básica de modelos de securitização de recebíveis no setor de saneamento v. 8 n. 16 p. $83-99$ jan./abr. 2008

BRAGA, Marcelo José

Risco de liquidez em cooperativas de crédito de Minas Gerais: uma abordagem a partir dos modelos discriminante e logit v. 8 n. 16 p. $61-82$ jan./abr. 2008

CARRIERI, Alexandre de Pádua

Feirante ou barraqueiro? Identidades e estratégias na Feira do Jubileu v. 8 n. 17 p. $70-87$ mai./ago. 2008

CASTRO, Dagmar Silva Pinto de

Caracterização do modelo organizacional de duas instituições do terceiro setor utilizando a teoria de Mintzberg

v. 8 n. 16 p. $48-60$ jan./abr. 2008

CIRINO, Jader Fernandes

Risco de liquidez em cooperativas de crédito de Minas Gerais: uma abordagem a partir dos modelos discriminante e logit

v. 8 n. 16 p. $61-82$ jan./abr. 2008

CORREIA, Fernanda Bruto da Costa

Uma análise sobre a aprendizagem em consultoria à luz da experiência

v. 8 n. 18 p. $72-91$ set./dez. 2008

COUTINHO, Gisela Aguiar Soares

Reestruturação da cadeia produtiva têxtil em Valença-RJ

v. 8 n. 17 mai./ago. 2008

FARIA, Marcos Áreas de

Perfil dos egressos do Programa de Mestrado Profissional em Administração da PUC Minas/FDC no período de 2000 a 2005

v. 8 n. 16 p. $100-118$ jan./abr. 2008

FARIA, Maria Vilma Coelho Moreira

Capital social e a formação de grupos solidários do Programa CrediAmigo: desafios e possibilidades v. 8 n. 17 p. $107-129$ mai./ago. 2008 
FARIAS, Iracema Quirino

Capital social e a formação de grupos solidários do Programa CrediAmigo: desafios e possibilidades v. 8 n. 17 p. $107-129$ mai./ago. 2008

FEITOSA, Marcos Gilson Gomes

Uma análise sobre a aprendizagem em consultoria à luz da experiência

v. 8 n. 18 p. $72-91$ set./dez. 2008

FISCHER, André Luiz

A aprendizagem organizacional como um campo específico de conhecimento no cenário dos estudos organizacionais

v. 8 n. 18 p. $10-31$ set./dez. 2008

FISCHER, André Luiz

Uma análise sobre a aprendizagem em consultoria à luz da experiência

v. 8 n. 18 p. $72-91$ set./dez. 2008

FREITAS, Henrique

Inteligência estratégica: desenvolvimento da capacidade de antecipação pela identificação e captação de indícios antecipativos

v. 8 n. 17 p. $100-118$ mai./ago. 2008

GONÇALVES, Carlos Alberto

Manifestações simbólicas nas relações intra e interorganizacionais

v. 8 n. 17 p. 51-69 mai./ago. 2008

GONÇALVES, Carlos Alberto

A dinâmica da aprendizagem intra e interorganizacional: perspectivas em estratégias cooperativas e competitivas utilizando as tipologias de exploration e exploitation

v. 8 n. 18 p. $134-150$ set./dez. 2008

GONÇALVES, Rosiane Maria Lima

Risco de liquidez em cooperativas de crédito de Minas Gerais: uma abordagem a partir dos modelos discriminante e logit

v. 8 n. 16 p. $61-82$ jan./abr. 2008

JANISSEK-MUNIZ, Raquel

Inteligência estratégica: desenvolvimento da capacidade de antecipação pela identificação e captação de indícios antecipativos

v. 8 n. 17 p. $100-118$ mai./ago. 2008

JÚNIOR, Vladas Urbanavícius

Caracterização do modelo organizacional de duas instituições do terceiro setor utilizando a teoria de Mintzberg

v. 8 n. 16 p. $48-60$ jan./abr. 2008

KELLER, Paulo Fernandes

Clusters, distritos industriais e cooperação interfirmas: uma revisão da literatura

v. 8 n. 16 p. $30-47$ jan./abr. 2008

KILIMNIK, Zélia Miranda

Manifestações simbólicas nas relações intra e interorganizacionais

v. 8 n. 17 p. 51-69 mai./ago. 2008 
LESCA, Humbert

Inteligência estratégica: desenvolvimento da capacidade de antecipação pela identificação e captação de indícios antecipativos

v. 8 n. 17 p. $100-118$ mai./ago. 2008

LOIOLA, Elisabeth

Aprendizagem organizacional das empresas do Prêmio Finep de Inovação

v. 8 n. 18 p. $32-52$ set./dez. 2008

MEURER, Aline Mara

$\mathrm{O}$ arrependimento do consumidor em compras on-line

v. 8 n. 17 p. $88-106$ mai./ago. 2008

MOURA, Ana Lúcia Neves de

Analisando o impacto da consultoria interna no setor público

v. 8 n. 18 p. $53-71$ set./dez. 2008

NAKATA, Lina Eiko

O ambiente de trabalho pode favorecer a gestão da inovação?

v. 8 n. 18 p. $152-157$ set./dez. 2008

OLIVEIRA, Caio César Giannini

Perfil dos egressos do Programa de Mestrado Profissional em Administração da PUC Minas/FDC no período de 2000 a 2005

v. 8 n. 16 p. $100-118$ jan./abr. 2008

PARDINI, Daniel Jardim

Manifestações simbólicas nas relações intra e interorganizacionais

v. 8 n. 17 p. 51-69 mai./ago. 2008

PARDINI, Daniel Jardim

A dinâmica da aprendizagem intra e interorganizacional: perspectivas em estratégias cooperativas e competitivas utilizando as tipologias de exploration e exploitation

v. 8 n. 18 p. $134-150$ set./dez. 2008

PAULA, Jéferson Olegário de

Caracterização do modelo organizacional de duas instituições do terceiro setor utilizando a teoria de Mintzberg

v. 8 n. 16 p. $48-60$ jan./abr. 2008

PERIN, Marcelo Gattermann

$\mathrm{O}$ arrependimento do consumidor em compras on-line

v. 8 n. 17 p. $88-106$ mai./ago. 2008

PORTO, Gênio

Aprendizagem organizacional das empresas do Prêmio Finep de Inovação

v. 8 n. 18 p. $32-52$ set./dez. 2008

REZENDE, Marcelo Lacerda 
Caracterização do modelo organizacional de duas instituições do terceiro setor utilizando a teoria de Mintzberg

v. 8 n. 16 p. $48-60$ jan./abr. 2008

ROGLIO, Karina de Déa

Caracterização do modelo organizacional de duas instituições do terceiro setor utilizando a teoria de Mintzberg

v. 8 n. 16 p. $48-60$ jan./abr. 2008

SAMPAIO, Cláudio Hoffmann

$\mathrm{O}$ arrependimento do consumidor em compras on-line

v. 8 n. 17 p. $88-106$ mai./ago. 2008

SANTOS, Renata Veloso

A dinâmica da aprendizagem intra e interorganizacional: perspectivas em estratégias cooperativas e competitivas utilizando as tipologias de exploration e exploitation v. 8 n. 18 p. $134-150$ set./dez. 2008

SILVA, Adriano José da

Descrição da estrutura básica de modelos de securitização de recebíveis no setor de saneamento

v. 8 n. 16 p. $83-99$ jan./abr. 2008

SOUZA, Bruno Campello de

Analisando o impacto da consultoria interna no setor público

v. 8 n. 18 p. $53-71$ set./dez. 2008

SOUZA, Mariana Mayumi Pereira de

Feirante ou barraqueiro? Identidades e estratégias na Feira do Jubileu

v. 8 n. 17 p. $70-87$ mai./ago. 2008

TAKADA, Cíntia Carla

A contribuição da gestão socialmente responsável para a aprendizagem em equipe: um estudo de caso na Copel

v. 8 n. 18 p. $92-110$ set./dez. 2008

TAKAHASHI, Adriana Roseli Wünsch

Aprendizagem organizacional e desenvolvimento de competências organizacionais: proposta metodológica para exploração conceitual e empírica

v. 8 n. 18 p. $112-132$ set./dez. 2008

TEIXEIRA, Dalton Jorge

Perfil dos egressos do Programa de Mestrado Profissional em Administração da PUC Minas/FDC no período de 2000 a 2005

v. 8 n. 16 p. $100-118$ jan./abr. 2008

VANZAN,Danielle Mendes Vanzan

O fenômeno da maldição do vencedor em leilões: um estudo experimental no ambiente brasileiro

v. 8 n. 16 p. $11-29$ jan./abr. 2008

VERSIANI, Ângela França

A aprendizagem organizacional como um campo específico de conhecimento no cenário dos estudos organizacionais 
v. 8 n. 18 p. $10-31$ set./dez. 2008

VIEIRA, Naldeir dos Santos

Uma análise sobre a aprendizagem em consultoria à luz da experiência v. 8 n. 18 p. $72-91$ set./dez. 2008 